\title{
Development of a novel IGRA assay to test $T$ cell responsiveness to HBV antigens in whole blood of chronic Hepatitis B patients
}

\author{
Werner Dammermann ${ }^{1 *}$, Frank Bentzien², Eva-Maria Stiel', Claudia Kühne1, Sebastian Ullrich³,
} Julian Schulze zur Wiesch ${ }^{1,4,5}$ and Stefan Lüth ${ }^{1,4}$

\begin{abstract}
Background: Interferon gamma release assays (IGRA) have been developed to support easy and fast diagnosis of diseases like tuberculosis, and CMV in transplant patients. IGRAs focus on cellular immunity especially memory T cells and thus also allow rapid screening prior to complex flow cytometric testing. Here, we describe a novel, sensitive whole blood based cytokine release assay capable of assessing T cell responsiveness to HBV antigens in Hepatitis B patients and assessing hepatitis B vaccination status in healthy individuals.

Methods: Seventy two chronic Hepatitis B patients (CHB), 8 acute hepatitis B patients (AHB) and 80 healthy controls (HC) were tested by ELISA for IFNY- and IL2-secretion in whole blood after challenge with synthetic peptide libraries of hepatitis B core antigen ( $\mathrm{HBCAg}$ ) or hepatitis B surface antigen ( $\mathrm{HBsAg}$ ).

Results: The developed IGRA test reliably differentiated between Hepatitis B patients, vaccinees and unvaccinated healthy controls. Treatment naïve and treated CHB patients showed a weaker IFNy response to $\mathrm{HBCAg}(16 \pm 5$ and $35 \pm 28 \mathrm{pg} / \mathrm{ml}$, respectively) compared to the AHB group $(82 \pm 39 \mathrm{pg} / \mathrm{ml})$, whereas HC remained unresponsive $(6 \pm$ $1 \mathrm{pg} / \mathrm{ml}$ ). IL2 levels after HBCAg challenge were also higher in the AHB group compared to naive and treated CHB as well as HC (47 \pm 21 vs. $12 \pm 3,15 \pm 10$ and $12 \pm 9 \mathrm{pg} / \mathrm{ml}$, respectively). HBsAg stimulation led to increased IFNy and IL2 levels in the AHB group ( $33 \pm 12$ and $22 \pm 12 \mathrm{pg} / \mathrm{ml}$ ) and even higher levels in HC due to a high hepatitis B vaccination rate $(41 \pm 10$ and $167 \pm 58 \mathrm{pg} / \mathrm{ml})$. Naive and treated CHB patients developed no or only weaker IFNy or IL2 responses to HBsAg ( $5 \pm 2$ and $12 \pm 7 \mathrm{pg} / \mathrm{ml}$, for naive $\mathrm{CHB}, 12 \pm 10$ and $18 \pm 15 \mathrm{pg} / \mathrm{ml}$, for treated CHB). For HC, IL2 release after HBsAg stimulation depicted hepatitis B vaccination status with a diagnostic sensitivity and specificity of $85 \%$ and $90 \%$.
\end{abstract}

Conclusion: Our novel whole blood based cytokine release assay constitutes an easy and robust tool for screening HBV specific cellular immunity as alternative to flow cytometry or ELISPOT assays.

Keywords: Chronic hepatitis B, HBV, Interferon gamma release assay, Cytokine release assay

\section{Introduction}

More than 240 million individuals are infected with chronic hepatitis B worldwide and are at risk to develop severe liver disease, liver cirrhosis or hepatocellular carcinoma [1]. A prophylactic hepatitis B vaccine has been available for over 3 decades and ensures long-term protection from infection [2]. However, development of a

\footnotetext{
*Correspondence: w.dammermann@uke.de

'Department of Medicine, University Medical Center Hamburg-Eppendorf, Martinistrasse 52, Hamburg 20246, Germany

Full list of author information is available at the end of the article
}

therapeutic vaccine for chronic hepatitis B patients has not met with success so far [3]. It is thought that one reason for lacking efficacy of such a therapeutic vaccine is that HBV-specific T lymphocytes show functional defects and exhaustion and lack proliferation in chronic hepatitis B $[4,5]$.

Effective prophylactic and therapeutic vaccines depend on strong humoral and cellular immune responses to infectious antigens as part of the vaccine formulation. Whereas in vaccine trials the humoral immune response is analyzed by standard serological assays, e.g. ELISA or 
western blot [6,7], cell-mediated immunity (CMI) is usually assessed by established and technically demanding analytical methods like flow cytometry, intracellular cytokine staining (ICS), ${ }^{3} \mathrm{H}$-thymidine proliferation assays or ELISPOT [5]. Therefore, whole blood based cytokine release assays or interferon gamma release assays (IGRA), respectively, may constitute a robust, easy and cost effective alternative as screening tools in studies of HBV Immunology and HBV vaccination studies.

Here, we describe the establishment of a whole blood based cytokine release assay capable of assessing $\mathrm{T}$ cell responsiveness to HBV peptide pools in chronic hepatitis B patients and hepatitis B vaccination status in healthy individuals.

\section{Methods}

\section{Patient selection}

Hepatitis B patients treated at the hepatitis outpatient department of the University Medical Center HamburgEppendorf were enrolled in the study for which all patients gave written consent and which was approved by the Ethics Committee of the Hamburg Chamber of Physicians (PV3941). Patients were stratified according to their clinical course into 3 groups (Table 1) with either NUC treatment naïve chronic Hepatitis B (CHB, NUC treatment naive, $n=40$ ), NUC treated chronic Hepatitis $\mathrm{B}$ (CHB, NUC treated, $\mathrm{n}=32$ ) or acute hepatitis $\mathrm{B}$ (AHB, $\mathrm{n}=8$ ). NUC are nucleoside/nucleotide analogues (NUC, tenofovir and/or entecavir) used for HBV specific antiviral treatment. Healthy donors of the blood transfusion service at the University Medical Center Hamburg-
Eppendorf were anonymously enrolled in the study as healthy controls $(\mathrm{HC}, \mathrm{n}=80)$. Additional clinical data for all patients and $\mathrm{HC}$ was provided (Table 1).

\section{Reagents}

The recall peptide pool CEFT was purchased from JPT, Germany (\#PM-CEFT) and solved in sterile dimethyl sulfoxide (DMSO; \#RO/A9941/000100, Th. Geyer, Germany) $25 \mathrm{mg} / \mathrm{ml}$ followed by storage at $-20{ }^{\circ} \mathrm{C}$. CEFT peptide pool consisted of antigenic peptides from human Cytomegalovirus (HHV-5; CMV), Epstein-Barr virus (HHV-4; EBV), Influenza A and Clostridium tetani. This positive control pool contained 27 peptides selected from defined HLA class I and II-restricted T-cell epitopes. Considering the high vaccination frequency against Influenza and C.tetani and the high prevalence of CMV and EBV in the general population in Germany recall antigen responses were expected for all patient samples. Staphylococcus aureus enterotoxin B superantigen (SEB) was obtained from Sigma Aldrich $\mathrm{GmbH}$, Germany (\#S4881) and stored $1 \mathrm{mg} / \mathrm{ml}$ in sterile, endotoxin-free $\mathrm{H}_{2} \mathrm{O}$ and $-20{ }^{\circ} \mathrm{C}$. Synthetic HBV peptide libraries of $\mathrm{HBcAg}$ and $\mathrm{HBsAg}$ were purchased from JPT, Germany (\#PM-HBV-CP and \#PM-HBV-lEP, respectively) and solved in sterile dimethyl sulfoxide (DMSO; \#RO/A9941/000100, Th. Geyer, Germany) $50 \mathrm{mg} / \mathrm{ml}$ followed by storage at $-20{ }^{\circ} \mathrm{C}$. Synthetic HBcAg represented a mix of 44 peptides (15 amino acid length each, 11 aa overlap, peptide scan 15/11) comprising the whole amino acid sequence of $\mathrm{HBcAg}$, the $21.5 \mathrm{kDa}$ capsid protein of HBV (genotype A2 subtype

Table 1 Characteristics of all subjects included in the study

\begin{tabular}{|c|c|c|c|c|c|}
\hline \multicolumn{6}{|l|}{ Characteristic } \\
\hline & & $H C^{b}$ & $A H B^{b}$ & $\mathrm{CHB}^{\mathrm{b}}, \mathrm{N} \cup \mathrm{C}$ treatment naive & $\mathrm{CHB}^{\mathrm{b}}, \mathrm{NUC}$ treated \\
\hline \multirow[t]{3}{*}{$n$} & & 80 & 8 & 40 & 32 \\
\hline & Male & 69 (86.3 \%) & $4(50 \%)$ & $20(50 \%)$ & $23(71.9 \%)$ \\
\hline & Female & $11(13.8 \%)$ & $4(50 \%)$ & $20(50 \%)$ & 9 (28.1\%) \\
\hline \multirow[t]{3}{*}{ Age $(y r)^{a}$} & & $40.6 \pm 12.0$ & $45.9 \pm 15$ & $43.4 \pm 14.9$ & $47.3 \pm 11.4$ \\
\hline & Male & $40.2 \pm 12.1$ & $49.7 \pm 11.8$ & $41.2 \pm 11.6$ & $50.1 \pm 11.2$ \\
\hline & Female & $43.7 \pm 11.5$ & $42.2 \pm 18.7$ & $45.7 \pm 17.6$ & $40.0 \pm 8.6$ \\
\hline $\operatorname{ALT}(U / I)^{a}$ & & n.d. ${ }^{c}$ & $1046.0 \pm 1035.0$ & $37.7 \pm 60.2$ & $42.9 \pm 39.3$ \\
\hline $\mathrm{AST}(\mathrm{U} /)^{\mathrm{a}}$ & & n.d. ${ }^{c}$ & $610.6 \pm 702.5$ & $26.6 \pm 27.9$ & $29.5 \pm 27.7$ \\
\hline HBV-DNA $(I U / m l)^{a}$ & & n.d. ${ }^{c}$ & $2.88^{*} 10^{6} \pm 7.7^{*} 10^{6}$ & $4.2^{*} 10^{7} \pm 1.8^{*} 10^{8}$ & $1.6^{*} 10^{7} \pm 8.8^{*} 10^{7}$ \\
\hline $\mathrm{HBsAg}(\mathrm{IU} / \mathrm{ml})^{\mathrm{a}}$ & & n.d. ${ }^{c}$ & $9153.4 \pm 10,378.9$ & $12,588.6 \pm 20,958.8$ & $4783.1 \pm 6326.3$ \\
\hline \multirow[t]{2}{*}{$\mathrm{HBeAg}$} & Negative & n.d. ${ }^{c}$ & $4(50 \%)$ & $34(85 \%)$ & $24(77.4 \%)$ \\
\hline & Positive & n.d. ${ }^{c}$ & $4(50 \%)$ & $6(15 \%)$ & 7 (22.6 \%) \\
\hline \multirow[t]{2}{*}{ Anti-HBs } & Negative & $41(51.2 \%)$ & $8(100 \%)$ & $36(90 \%)$ & $32(100 \%)$ \\
\hline & Positive & $33(41.3 \%)$ & $0(0 \%)$ & $4(10 \%)$ & $0(0 \%)$ \\
\hline
\end{tabular}

${ }^{a}$ The data are shown as means \pm standard deviations

${ }^{\mathrm{b}} \mathrm{HC}=$ healthy controls, $\mathrm{AHB}=$ acute hepatitis $\mathrm{B}, \mathrm{CHB}=$ chronic hepatitis $\mathrm{B}$

c n.d. $=$ not determined 
adw2, UniProt: P0C693). Synthetic HBsAg represented a mix of 98 peptides (15 amino acid length each, 11 aa overlap, peptide scan 15/11) comprising the whole amino acid sequence of $\mathrm{HBsAg}$, the $43.7 \mathrm{kDa}$ surface protein of HBV (genotype A2 subtype adw2, UniProt: P17101).

\section{Cytokine release assay in whole blood ex vivo}

Venous blood was collected from hepatitis B patients and $\mathrm{HC}$ into sterile $7.5 \mathrm{ml}$ Lithium heparin Monovettes (Sarstedt, Germany). $1 \mathrm{ml}$ of whole blood was then dispensed into sterile, pyrogen free $2 \mathrm{ml}$ tubes with screw caps (Sarstedt, Germany) within $4 \mathrm{~h}$ of collection preloaded with sterile $0.9 \%(\mathrm{w} / \mathrm{v}) \mathrm{NaCl}$ solution (negative control), SEB ( $1^{\text {st }}$ positive control), recall CEFT peptide pools $\left(2^{\text {nd }}\right.$ positive control) or HBV peptide pools. In all tubes, glucose $(2 \mathrm{mg} / \mathrm{mI}$ final concentration; pre-diluted in sterile $0.9 \%(\mathrm{w} / \mathrm{v}) \mathrm{NaCl}$ solution; \#HN06.1, Carl Roth, Germany) was used to further enhance cytokine secretion, which had been tested before using various antigens (Additional file 1: Online resource 1).

Thus, whole blood was stimulated with a total volume of $120 \mu \mathrm{l} /$ tube of $\mathrm{NaCl} \&$ glucose (negative control), $120 \mu \mathrm{l} /$ tube SEB \& glucose $(1 \mu \mathrm{g} / \mathrm{ml}$ final concentration after dilution out of stock, $1^{\text {st }}$ positive control), $120 \mu \mathrm{l} /$ tube recall antigen CEFT \& glucose $(10 \mu \mathrm{g} / \mathrm{ml}$ final concentration after dilution out of stock, $2^{\text {nd }}$ positive control) or $120 \mu \mathrm{l} /$ tube HBV peptide pools $(50 \mu \mathrm{g} / \mathrm{ml}$ final concentration after dilution out of stock). All HBV peptide pools were titrated for maximum cytokine responses in advance. SEB served as a $1^{\text {st }}$ positive control due to its superantigenic properties by cross-linking MHC molecules with T-cell receptors, which proved the general viability of all samples. CEFT was introduced as a $2^{\text {nd }}$ positive control to prove the functionality of antigen presenting cells in all samples.

The tubes were closed and incubated at $37{ }^{\circ} \mathrm{C}$ for $24 \mathrm{~h}$. Thereafter, plasma supernatants were aspirated, pooled, stabilized with $0.045 \%(\mathrm{w} / \mathrm{v}) \mathrm{NaN}_{3}$ and stored at $-20{ }^{\circ} \mathrm{C}$ until assayed for cytokines within the next 7 days. A $5 \%(\mathrm{v} / \mathrm{v}) \mathrm{CO}_{2}$ atmosphere was proven to be unnecessary (data not shown) and yielded results comparable to stimulation in the presence of $\mathrm{CO}_{2}$.

\section{IFNY and IL2 ELISAs}

Detection of total / overall amounts of IFNY and IL2 in human plasma was conducted using ELISA MAX Deluxe sets from Biolegend, Germany: IFNY (\#430106) and IL2 (\#431806). The manufacturer's Avidin-horseradish peroxidase conjugate was replaced by PolyHRP80 streptavidine conjugate (\#SP80C, SDT Reagents, Germany) in order to achieve a tenfold lower limit of detection. Lower limit of detection (Background $+3 x$ S.D.) was generally at $2-5 \mathrm{pg} / \mathrm{ml}$ for IFNY and IL2, respectively.
Initial dilution of control and test samples was performed described as follows: negative control $(\mathrm{NaCl})$ $1 / 5,1^{\text {st }}$ positive control (SEB) $1 / 2500$ for IFN $\gamma$ and $1 / 500$ for IL2, $2^{\text {nd }}$ positive control (CEFT) $1 / 50$ for IFNy and $1 / 25$ for IL2, test samples (HBcAg and HBsAg) $1 / 5$. If a test sample's absorbance value fell outside the maximum standard curve range, these samples were subsequently retested with a tenfold higher dilution, e.g. $1 / 5 \rightarrow 1 / 50, \quad 1 / 500 \rightarrow 1 / 5000, \quad 1 / 2500 \rightarrow 1 / 25000 . \quad$ A seven-point standard curve from $1-64 \mathrm{pg} / \mathrm{ml} \mathrm{IFN \gamma}$ or IL2 was used for quantitation. Standards, controls and test samples were measured in duplicate. The samples were analyzed using Magellan software (version 6.5) equipped on a Tecan M200 plate reader.

\section{Data analysis}

\section{Software}

The ELISA data was analyzed using SigmaPlot software (Systat Software Inc., version number 12.2) and GraphPad Prism software (Graphpad Software Inc., version number 6.04).

\section{Statistical analysis}

Descriptive statistics, ANOVA including Tamhane T2 post hoc tests and prior normality tests, unpaired $t$-test and receiver operating characteristic (ROC) analysis were performed using SPSS Statistics software (IBM, version number 22), SigmaPlot software (Systat software Inc., version number 12.2) and GraphPad Prism software (Graphpad Software Inc., version number 6.04). Negative control values were deducted from the peptide induced responses prior to statistical analysis. Intra-assay and inter-assay variability could not be assessed due to limited amounts of whole blood per patient.

\section{Results}

IFNy responses to $\mathrm{HBCAg}$ in whole blood of $\mathrm{CHB}$ patients are reduced compared to AHB patients

Two major $\mathrm{HBV}$ proteins, $\mathrm{HBcAg}$ and $\mathrm{HBsAg}$, were tested in an HBV specific cytokine release assay with $\mathrm{HC}$ and 3 different hepatitis B patient groups: acute, NUC treatment naïve and NUC treated chronic hepatitis B. Stimulation of whole blood with sterile $0.9 \%$ (w/v) $\mathrm{NaCl}$ solution (negative control), SEB ( $1^{\text {st }}$ positive control) and CEFT ( $2^{\text {nd }}$ positive control) confirmed the viability of all collected samples (Fig. 1. and Table 2).

Synthetic $\mathrm{HBcAg}$-specific peptides elicited higher IFN $\gamma$ responses in $\mathrm{AHB}$ than treatment naïve and treated CHB patients (Fig. 2a, Table $3 ; 82 \pm 39$ vs. $16 \pm 5$ and $35 \pm 28 \mathrm{pg} / \mathrm{ml} ; \mathrm{p}=0.78$ and $\mathrm{p}=0.98)$. HC did not show any reaction towards $\mathrm{HBcAg}$ in whole blood compared to $\mathrm{AHB}$ patients $(6 \pm 1$ vs. $82 \pm 39 \mathrm{pg} / \mathrm{ml}, \mathrm{p}=0.62)$. Synthetic HBsAg peptides induced comparable IFN $\gamma$ responses in $\mathrm{HC}$ and $\mathrm{AHB}$ patients (Fig. 2a; $41 \pm 10$ vs. 


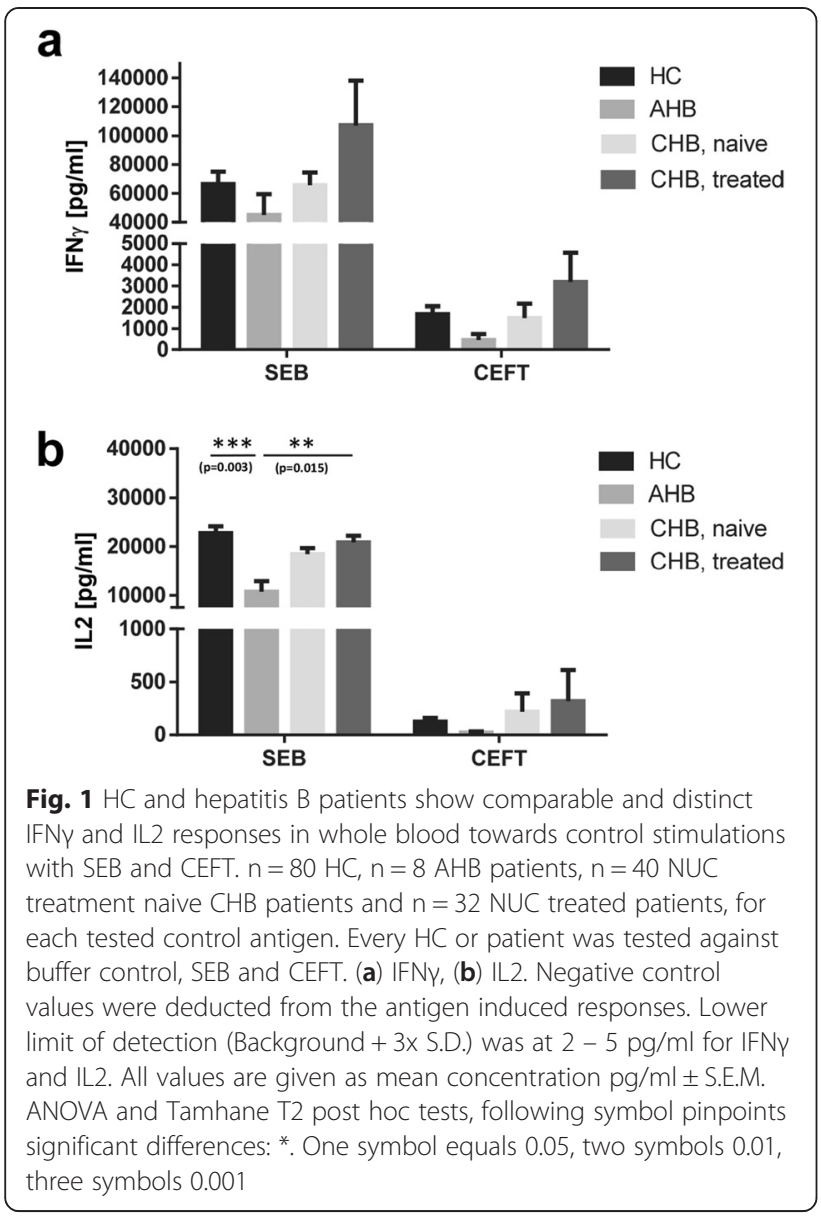

$33 \pm 12 \mathrm{pg} / \mathrm{ml} ; \mathrm{p}=0.99)$, but weaker responses in naïve as well as treated $\mathrm{CHB}$ patients $(5 \pm 2$ and $12 \pm 10 \mathrm{pg} / \mathrm{ml}$; naïve $\mathrm{CHB}$ vs. $\mathrm{HC} \mathrm{p}=0.003$ and naïve $\mathrm{CHB}$ vs. $\mathrm{AHB}$ $\mathrm{p}=0.46$; treated $\mathrm{CHB}$ vs. $\mathrm{HC} \mathrm{p}=0.28$ and treated $\mathrm{CHB}$ vs. AHB $\mathrm{p}=0.9$ ).

IL2 responses were generally comparable to IFNY responses regarding total cytokine amounts (Fig. 2b). $\mathrm{HBcAg}$ induced IL2 synthesis in AHB (47 $\pm 21 \mathrm{pg} / \mathrm{ml})$, but not naïve and treated $\mathrm{CHB}$ patients as well as $\mathrm{HC}$ $(12 \pm 3,15 \pm 10$ and $12 \pm 9 \mathrm{pg} / \mathrm{ml} ; \mathrm{p}=0.78, \mathrm{p}=0.89$ and $\mathrm{p}=0.82$ ). HBsAg elicited significantly higher IL2 responses in $\mathrm{HC}(167 \pm 58 \mathrm{pg} / \mathrm{ml})$ compared to AHB, naïve and treated $\mathrm{CHB}$ patients $(22 \pm 12,12 \pm 7$ and $18 \pm 15 \mathrm{pg} / \mathrm{m} ; \mathrm{p}=0.05, \mathrm{p}=0.03$ and $\mathrm{p}=0.04$ ).

Taken together, cytokine release assays using $\mathrm{HBcAg}$ stimulation in whole blood are able to depict the (hypo-) responsiveness of $\mathrm{HBV}$-specific $\mathrm{T}$ cells in $\mathrm{CHB}$ patients.

\section{$\mathrm{HBeAg}+\mathrm{CHB}$ patients show weaker cytokine responses to $\mathrm{HBCAg}$ and $\mathrm{HBsAg}$ than $\mathrm{HBeAg}-\mathrm{CHB}$ patients}

All NUC treatment naïve and NUC treated $72 \mathrm{CHB}$ patients were stratified according to $\mathrm{HBeAg}$ status as well as HBV-DNA status and subsequently tested for IFN $\gamma$ and IL2-secretion in whole blood after challenge with synthetic HBcAg- and HBsAg-specific peptides by ELISA. Stimulation with $\mathrm{HBcAg}$-specific peptides led to higher IFNY concentrations in plasma of treated, but not naive $\mathrm{HBeAg}-\mathrm{CHB}$ patients compared to $\mathrm{HBeAg}+\mathrm{pa}-$ tients (Fig. $3 \mathrm{a}-\mathrm{b} ; 17 \pm 6$ vs. $12 \pm 9 \mathrm{pg} / \mathrm{ml}$ for naïve CHB; $46 \pm 37$ vs. $3 \pm 1 \mathrm{pg} / \mathrm{ml}$ for treated $\mathrm{CHB}$, respectively). Stimulation with HBsAg-specific peptides was also more prominent in treated, but not naive $\mathrm{HBeAg}-\mathrm{CHB}$ patients compared to $\mathrm{HBeAg}$ + patients $(6 \pm 2$ vs. $1 \pm 1 \mathrm{pg} /$ $\mathrm{ml}$ for naïve $\mathrm{CHB}$ and $16 \pm 13$ vs. $1 \pm 1 \mathrm{pg} / \mathrm{ml}$ for treated $\mathrm{CHB}$, respectively). IL2 responses yielded a comparable pattern with stronger cytokine production in plasma of HBeAg- CHB patients compared to HBeAg + patients: treated HBeAg- CHB patients gave higher IL2 levels than $\mathrm{HBeAg}+\mathrm{CHB}$ patients (Fig. 3d; $20 \pm 13$ vs. $1 \pm$ $1 \mathrm{pg} / \mathrm{ml}$ for $\mathrm{HBcAg}$ and $24 \pm 20$ vs. $1 \pm 1 \mathrm{pg} / \mathrm{ml}$ for HBsAg, respectively), whereas effects of $\mathrm{HBcAg}$ and HBsAg stimulation on IL2 levels in plasma of naïve CHB patients were negligible (Fig. 3c).

Regarding HBV-DNA status we looked for effects of viral load on the cytokine responses directed against HBcAg and HBsAg, but unlike HBeAg status viral load did not seem to influence cytokine production in a similar fashion: low HBV-DNA titers $\leq 50 \mathrm{IU} / \mathrm{ml}$ did not always coincide with higher cytokine levels after $\mathrm{HBcAg}$ or HBsAg stimulation in treatment naïve and NUC treated CHB patients (Fig. $3 e-h$ ).

In conclusion, $\mathrm{HBeAg}+$ treatment naïve and NUC treated $\mathrm{CHB}$ patients showed the weakest cytokine

Table 2 Positive and negative controls

\begin{tabular}{|c|c|c|c|c|c|c|c|}
\hline \multirow[t]{2}{*}{ Assay } & \multicolumn{2}{|c|}{$\mathrm{NaCl}$ (negative control) $^{\mathrm{a}}$} & \multicolumn{2}{|c|}{ SEB (1. positive control) ${ }^{a}$} & \multicolumn{3}{|c|}{ CEFT (2. positive control) } \\
\hline & IFNy [pg/ml] & IL2 [pg/ml] & IFNy [pg/ml] & IL2 [pg/ml] & IFNy [pg/ml] & $\mathrm{IL} 2[\mathrm{pg} / \mathrm{ml}]$ & $\mathrm{N}$ \\
\hline \multicolumn{8}{|l|}{ Group } \\
\hline$H C^{b}$ & $8 \pm 2$ & $2 \pm 1$ & $66,537 \pm 8485$ & $22,762 \pm 1399$ & $1681 \pm 361$ & $125 \pm 36$ & 80 \\
\hline$A H B^{b}$ & $15 \pm 5$ & $3 \pm 1$ & $45,083 \pm 14,487$ & $10,737 \pm 2148$ & $458 \pm 278$ & $22 \pm 11$ & 8 \\
\hline $\mathrm{CHB}^{\mathrm{b}}, \mathrm{NUC}$ treatment naive & $41 \pm 22$ & $1 \pm 1$ & $65,734 \pm 8837$ & $18,439 \pm 1244$ & $1490 \pm 669$ & $220 \pm 173$ & 40 \\
\hline $\mathrm{CHB}^{\mathrm{b}}, \mathrm{NUC}$ treated & $17 \pm 6$ & $2 \pm 1$ & $107,200 \pm 30,799$ & $20,838 \pm 1357$ & $3186 \pm 1383$ & $318 \pm 293$ & 32 \\
\hline
\end{tabular}

${ }^{\mathrm{a}}$ The data are shown as means \pm standard error of mean (S.E.M.). SEB and CEFT values are given after deduction of background values (NaCl, negative control)

${ }^{\mathrm{b}} \mathrm{HC}=$ healthy controls, $\mathrm{AHB}=$ acute hepatitis $\mathrm{B}, \mathrm{CHB}=$ chronic hepatitis $\mathrm{B}$ 


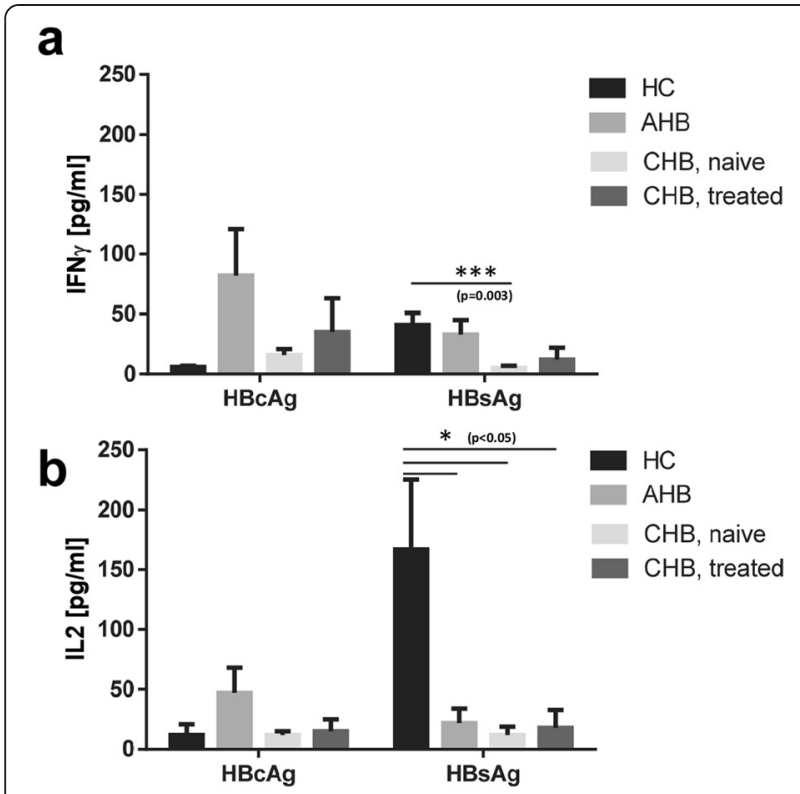

Fig. 2 Synthetic HBCAg peptides elicit weak IFNY and IL2 responses during HBV-specific T cell stimulation in whole blood of CHB patients. $n=80 \mathrm{HC}, \mathrm{n}=8 \mathrm{AHB}$ patients, $\mathrm{n}=40 \mathrm{NUC}$ treatment naive CHB patients and $n=32$ NUC treated patients, for each tested HBV antigen. Every $\mathrm{HC}$ or patient was tested against HBV peptide pools specific for HBCAg and HBsAg. (a) IFNy, (b) IL2. Negative control values were deducted from the peptide induced responses. Lower limit of detection (Background $+3 \times$ S.D.) was at $2-5 \mathrm{pg} / \mathrm{ml}$ for IFNY and IL2. All values are given as mean concentration $\mathrm{pg} / \mathrm{ml} \pm$ S.E.M. ANOVA and Tamhane T2 post hoc tests, following symbol pinpoints significant differences: *. One symbol equals 0.05 , two symbols 0.01 , three symbols 0.001

responses to HBV antigen-specific peptide challenge of all hepatitis B patient groups.

Treatment naïve $\mathrm{CHB}$ patients show comparable cytokine responses to $\mathrm{HBCAg}$ and $\mathrm{HBsAg}$ compared to NUC treated CHB patients in whole blood

$72 \mathrm{CHB}$ patients were stratified according to treatment status with nucleoside/nucleotide analogues (NUC, tenofovir and/or entecavir) and subsequently tested for IFN $\gamma$ - and IL2-secretion in whole blood after challenge with synthetic HBcAg and HBsAg peptides by ELISA.
HBcAg and HBsAg stimulation did not result in significant differences regarding IFNy concentrations in plasma of treatment naïve patients compared to NUC treated patients (Fig. 4a; $16 \pm 5$ vs. $35 \pm 28 \mathrm{pg} / \mathrm{ml}$ for $\mathrm{HBcAg}$ and $5 \pm 2$ vs. $12 \pm 10 \mathrm{pg} / \mathrm{ml}$ for $\mathrm{HBsAg}$, respectively). Likewise, IL2 responses to $\mathrm{HBcAg}$ and $\mathrm{HBsAg}$ in whole blood yielded no significant differences in view to treatment status (Fig. 4b; $12 \pm 3$ vs. $15 \pm 1 \mathrm{pg} / \mathrm{ml}$ for $\mathrm{HBcAg}$ and $12 \pm 10$ vs. $18 \pm 15 \mathrm{pg} / \mathrm{ml}$ for HBsAg, respectively).

NUC treatment had no significant positive effect on cytokine release in whole blood after stimulation with $\mathrm{HBcAg}$ and HBsAg-specifc peptides ex vivo.

\section{IL2 responses to $\mathrm{HBsAg}$ in $\mathrm{HC}$ correlate with hepatitis B vaccination status}

HBsAg constitutes the single main antigen in hepatitis B vaccine formulations. Thus, $74 \mathrm{HC}$ with known hepatitis $B$ vaccination status were also analyzed regarding their $\mathrm{HBsAg-dependent} \mathrm{IFN \gamma}$ and IL2 release. 33/74 HC possessed a positive anti-HBs antibody titer and $41 / 74$ were anti-HBs negative. Whereas IFN $\gamma$ responses were negligible, IL2 values reached marked heights if the tested individual had been successfully vaccinated (Fig. 5b), but these IL2 levels did not correlate with the corresponding anti-HBs antibody titer (Fig. 6). To determine the cut-off value of our newly developed assay, we performed a ROC analysis of the IL2 readings (Fig. 5a). This HBV specific cytokine release assay with HBsAg-specific peptides using IL2 release as the primary readout (cut-off = $11 \mathrm{pg} / \mathrm{ml}$ IL2) reached $85 \%$ diagnostic sensitivity and $90 \%$ diagnostic specificity. The corresponding AUC value was at 0.92 . Using the cut-off defined by the ROC analysis, as shown in Fig. 4, 28 (of 33) vaccinated HC showed positive scores, while 4 (of 41) not vaccinated $\mathrm{HC}$ slightly exceeded the cut-off value (Fig. 5b).

\section{Discussion}

Cytokine release assays using whole blood depict (hypo-) responsiveness of HBV-specific T cells in CHB patients

The group of Boni et al. delivered key data regarding the HBV specific cellular immune status under treatment

Table 3 HBcAg and HBsAg stimulations

\begin{tabular}{|c|c|c|c|c|c|}
\hline \multirow[t]{2}{*}{ Assay } & \multicolumn{2}{|l|}{$\mathrm{HBCAg}^{\mathrm{a}}$} & \multicolumn{3}{|l|}{$\mathrm{HBsAg}^{\mathrm{a}}$} \\
\hline & IFNy [pg/ml] & IL2 [pg/ml] & IFNy $[\mathrm{pg} / \mathrm{ml}]$ & IL2 [pg/ml] & N \\
\hline \multicolumn{6}{|l|}{ Group } \\
\hline$H C^{b}$ & $6 \pm 1$ & $12 \pm 9$ & $41 \pm 10$ & $167 \pm 58$ & 80 \\
\hline$A H B^{b}$ & $82 \pm 39$ & $47 \pm 21$ & $33 \pm 12$ & $22 \pm 12$ & 8 \\
\hline $\mathrm{CHB}^{\mathrm{b}}, \mathrm{NUC}$ treatment naive & $16 \pm 5$ & $12 \pm 3$ & $5 \pm 2$ & $12 \pm 7$ & 40 \\
\hline $\mathrm{CHB}^{\mathrm{b}}, \mathrm{NUC}$ treated & $35 \pm 28$ & $15 \pm 10$ & $12 \pm 10$ & $18 \pm 15$ & 32 \\
\hline
\end{tabular}

${ }^{\mathrm{a}}$ The data are shown as means \pm standard error of mean (S.E.M.). $\mathrm{HBCAg}$ and $\mathrm{HBsAg}$ values are given after deduction of background values (NaCl, negative control) ${ }^{\mathrm{b}} \mathrm{HC}=$ healthy controls, $\mathrm{AHB}=$ acute hepatitis $\mathrm{B}, \mathrm{CHB}=$ chronic hepatitis $\mathrm{B}$ 


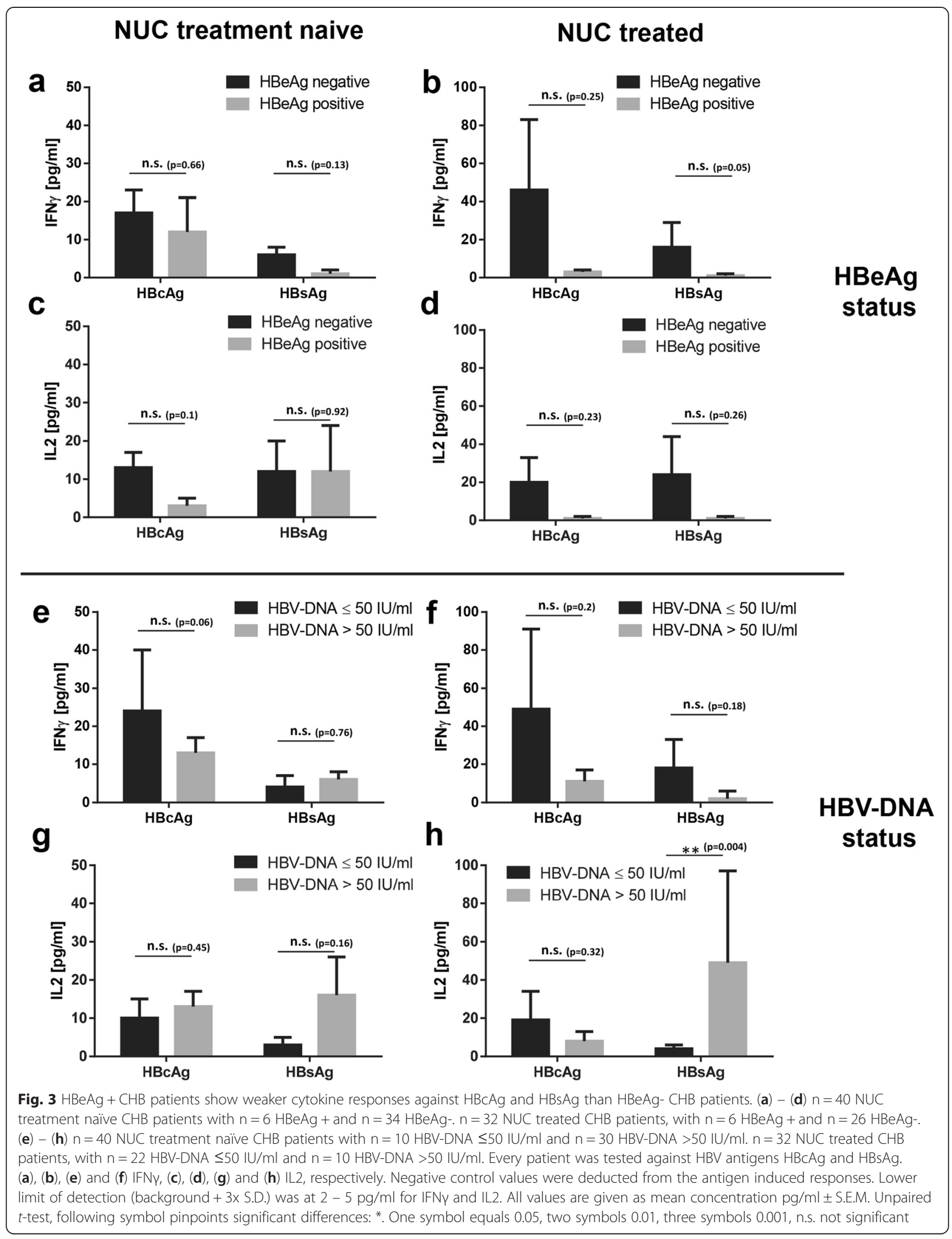



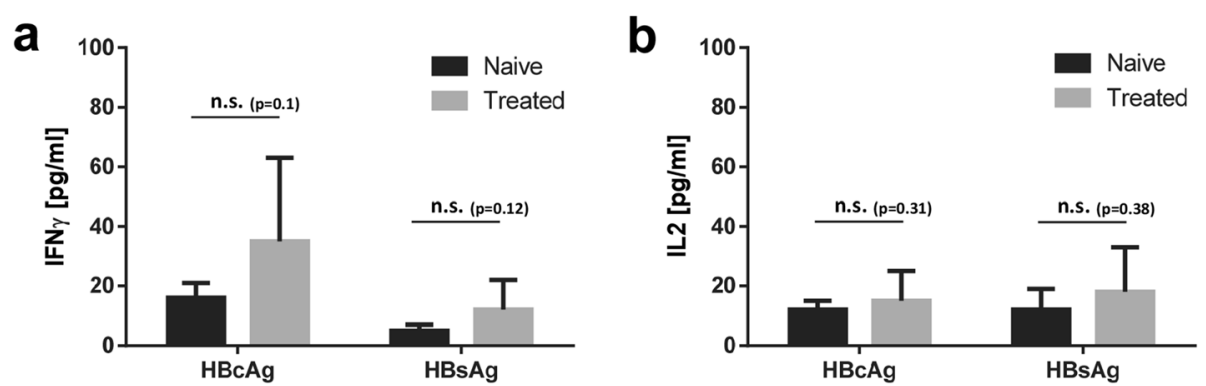

Fig. $4 \mathrm{NUC}$ treated $\mathrm{CHB}$ patients show comparable cytokine responses to $\mathrm{HBCAg}$ and $\mathrm{HBs} A g$ compared to treatment naïve $\mathrm{CHB}$ patients in whole blood. Lower limit of detection (Background $+3 \times$ S.D.) was at $2-5 \mathrm{pg} / \mathrm{ml}$ for IFNY and IL2. $n=72$ CHB patients, whereas $n=40$ NUC treatment naive and $n=32 \mathrm{NUC}$ treated. Every patient was tested against HBV antigens HBCAg and HBsAg. (a) IFNy, (b) IL2. Negative control values were deducted from the antigen induced responses. All values are given as mean concentration $\mathrm{pg} / \mathrm{ml} \pm$ S.E.M. Unpaired $t$-test, following symbol pinpoints significant differences: ${ }^{*}$. One symbol equals 0.05 , two symbols 0.01 , three symbols 0.001 , n.s. not significant

with first (lamivudine) or second generation drugs (tenofovir and entecavir) in consecutive and longitudinal clinical studies on HBV specific cellular immunity in $\mathrm{CHB}$ patients $[4,5]$. In most cases a restoration of anti-viral $\mathrm{T}$ cell responses could be observed after in vitro expansion, but not directly ex vivo $[4,5]$.

Our current results mirror these findings, since no significant recovery of the cytokine responses to $\mathrm{HBcAg}$ and HBsAg could be observed in NUC treated CHB patients in whole blood ex vivo. Interestingly, we detected the strongest IFN $\gamma$ and IL2 responses to $\mathrm{HBcAg}$ stimulation in a small pilot group of resolved hepatitis B patients $(109 \pm 27$ and $309 \pm 143 \mathrm{pg} / \mathrm{ml}, \mathrm{n}=3)$ that we measured for exploratory reasons compared to all other groups, whereas the IL2 response to HBsAg was negligible in contrast to $\mathrm{HC}(35 \pm 4 \mathrm{vs} 165 \pm 58 \mathrm{pg} / \mathrm{ml})$. It will be intriguing to further analyze this group of patients in follow-up studies i.e. to understand in how far the size of the immune response in our assays can predict patients that are at risk of HBV reactivation under immune suppression.

This suppressed $\mathrm{T}$ cell state is ongoing even after initiating successful treatment probably due to initially high viral or antigen load and might partially explain why clinical trials with therapeutic hepatitis $B$ vaccines and anti-viral drugs have not been effective so far, whereas treatment safety was generally achieved [8-11]. In these studies, HBV-specific cell mediated immunity and especially the $\mathrm{T}$ cell (hypo)-responsiveness of $\mathrm{CHB}$ patients was analyzed by established techniques, e.g. flow cytometry, intracellular cytokine staining (ICS), ${ }^{3} \mathrm{H}$-thymidine proliferation assays or ELISPOT.

We have demonstrated the suitability of whole blood based cytokine release assays to analyze T cell (hypo-) responsiveness in $\mathrm{CHB}$ patients and were even able to differentiate the suppressed $\mathrm{T}$ cell state further into $\mathrm{HBeAg}+$ $\mathrm{CHB}$ patients with stronger suppression than HBeAgCHB patients. Thus, we propose our protocol as an additional easy-to-use, cost efficient and robust tool for future therapeutic hepatitis B vaccination studies.

\section{IL2 responses after HBsAg-specific peptide stimulation} allow assessment of Hepatitis B vaccination status in $\mathrm{HC}$ Another important aspect of hepatitis B vaccination studies is the emergence of non- and low-responders to
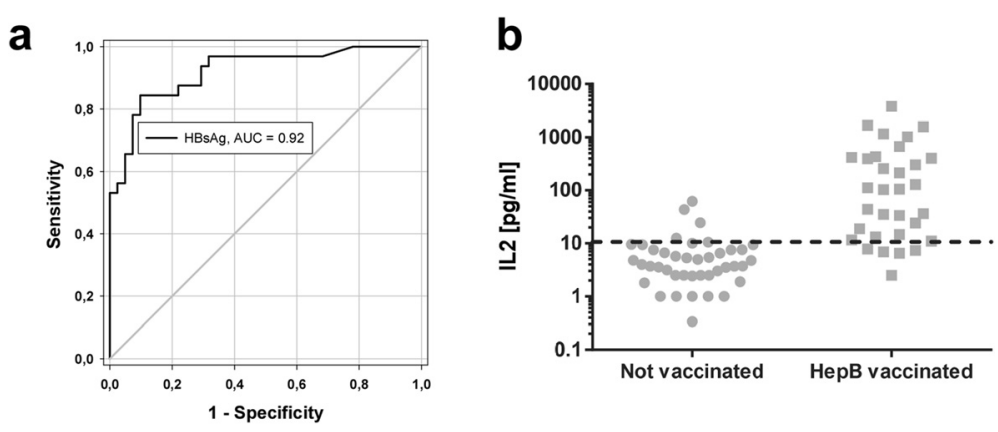

Fig. 5 IL2 responses to HBsAg in HC correlate with hepatitis B vaccination status. (a) Receiver-operating-characteristic (ROC) Curve. AUC, area under the curve. (b) Scatter plot of IL2 release of HepB vaccinated and not vaccinated HC after HBsAg stimulation of whole blood. Negative control values were deducted from the antigen induced responses. Dotted line indicates IL2 cut-off at $11 \mathrm{pg} / \mathrm{ml} . \mathrm{n}=74 \mathrm{HC}$, whereas $n=33$ were anti-HBs positive and $n=41$ anti-HBs negative 


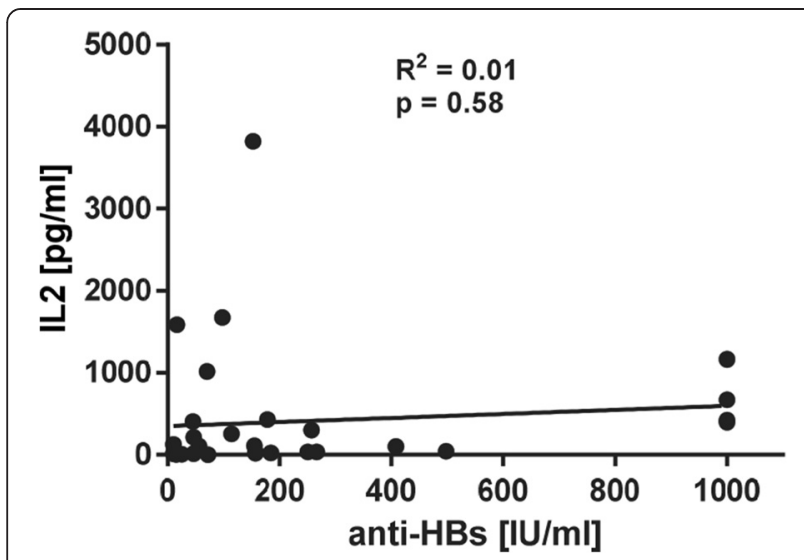

Fig. 6 Anti-HBs titers and strength of IL2 response do not correlate in hepatitis B vaccinated HC. Scatter plot of IL2 release of HepB vaccinated $\mathrm{HC}$ after $\mathrm{HBsAg}$ stimulation vs. anti-HBs titers. Negative control values were deducted from the antigen induced responses. Continuous line indicates linear regression and Pearson correlation. $R^{2}$ : coefficient of determination

vaccination and of previously successfully vaccinated subjects who lost their protective anti-HBs titers over time $[12,13]$. In these cases the question arises whether hepatitis B immunity is completely absent with no humoral and cellular immunologic memory or only partial, namely with hepatitis B specific cellular immunity present. The group of Bauer and Jilg proved the presence of significant numbers of HBsAg-specific memory $\mathrm{T}$ and $\mathrm{B}$ cells in a group of 15 healthy individuals who were successfully vaccinated but had lost anti-HBs titers [13]. A different study used a prototypic third generation HBV vaccine, Sci-B-Vac ${ }^{\mathrm{Ta}}$, containing small S, PreS1 and PreS2 antigens to trigger cellular and humoral immunity in healthy individuals who failed immunization with conventional vaccines [12]. 15 non-responders and 6 low-responders were included. After three vaccinations, 20/ 21 subjects developed protective anti-HBs titers $\geq 10 \mathrm{IU} / \mathrm{l}$, whereas 8/15 non-responders and 5/6 low-responders showed $\mathrm{HBsAg}$-specific $\mathrm{T}$ cell immunity using proliferation assays and IFN $\gamma$ release assays.

In these studies ${ }^{3} \mathrm{H}$-thymidine proliferation assays or IFN $\gamma$ ELISPOT assays were used to analyze HBVspecific cell-mediated immunity. Both assay types represent well-established techniques using lymphocytes isolated from peripheral blood (PBMCs). However, the direct use of whole blood ex vivo and the cytokine IL2 as a novel $\mathrm{T}$ cell readout marker might be an attractive alternative in case of future hepatitis B vaccination studies. Our results clearly depicted the hepatitis B vaccination status in healthy individuals and thus should be considered equal to the aforementioned techniques. Interestingly, a strong IL2 response was not mirrored by an equally high antibody titer thus adding valuable information on the immune status. Integrating both humoral and cellular data potentially could give us critical insights regarding overall humoral and cellular immunity towards HBV.

We propose our assay as fast and cost-effective tool for initial screenings of specimen to identify specific candidates which could then subsequently be tested by more technically demanding analytical methods like flow cytometry or ELISPOT.

\section{Conclusion}

We have established a protocol which is capable of analyzing the responsiveness of $\mathrm{HBV}$-specific $\mathrm{T}$ cells in patients with chronic hepatitis $\mathrm{B}$ infection using whole blood directly for testing without further sample preparation. In addition, we are able to assess the hepatitis B vaccination status of healthy blood donors on the cellular immunity level.

This novel IGRA constitutes an additional easy-to-use, cost-efficient and robust tool for screening HBV specific cellular immunity alone or in addition to other more technically demanding follow-up analytical methods like flow cytometry or ELISPOT.

\section{Additional file}

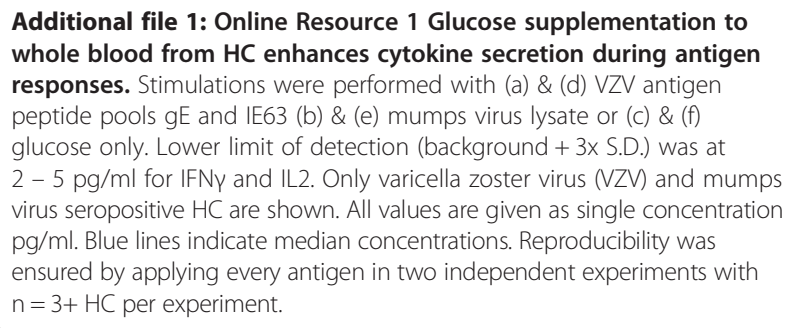

Competing interests

The authors declare that they have no competing interest.

\section{Authors' contributions}

Study design: WD, SU, JSzW and SL; patient selection: WD, SL, JSzW and FB; Sample analysis and interpretation: WD, EMS and CK; Statistics: WD and EMS; Manuscript writing: WD, JSzW, SU and SL. All authors have read and approved the final manuscript.

\section{Acknowledgments}

We thank the donors who participate in this study. We also thank Katharina Heinzel (1. Department of Medicine, University Medical Center HamburgEppendorf, Germany) for excellent technical assistance. SL is supported by the Deutsche Forschungsgemeinschaft (DFG), grant \# LU 1362/2-1 581069. $\mathrm{JSzW}$ is supported by the Deutsche Forschungsgemeinschaft (SFB 841, A6) and the German center for Infection Research (DZIF).

\section{Author details}

${ }^{1}$ Department of Medicine, University Medical Center Hamburg-Eppendorf, Martinistrasse 52, Hamburg 20246, Germany. ${ }^{2}$ Department of Transfusion Medicine, University Medical Center Hamburg-Eppendorf, Martinistrasse 52, Hamburg 20246, Germany. ${ }^{3}$ Department of Anatomy and Experimental Morphology, University Medical Center Hamburg-Eppendorf, Hamburg, Germany. ${ }^{4}$ German Center for Infection Research (DZIF), partner site Hamburg, Hamburg, Germany. ${ }^{5}$ Heinrich Pette Institute - Leibniz Institute for Experimental Virology, Hamburg, Germany. 
Received: 21 November 2014 Accepted: 4 May 2015

Published online: 13 May 2015

\section{References}

1. Ott JJ, Stevens GA, Groeger J, Wiersma ST. Global epidemiology of hepatitis $B$ virus infection: new estimates of age-specific HBsAg seroprevalence and endemicity. Vaccine. 2012;30(12):2212-9.

2. Huang LM, Lu CY, Chen DS. Hepatitis B virus infection, its sequelae, and prevention by vaccination. Curr Opin Immunol. 2011;23(2):237-43.

3. Liu J, Kosinska A, Lu M, Roggendorf M. New therapeutic vaccination strategies for the treatment of chronic hepatitis B. Virol Sin. 2014;29(1):10-6.

4. Boni C, Penna A, Bertoletti A, Lamonaca V, Rapti I, Missale G, et al. Transient restoration of anti-viral T cell responses induced by lamivudine therapy in chronic hepatitis B. J Hepatol. 2003;39(4):595-605.

5. Boni C, Laccabue D, Lampertico P, Giuberti T, Vigano M, Schivazappa S, et al. Restored function of HBV-Specific T Cells after Long-term effective therapy with Nucleos(t)ide Analogues. Gastroenterology. 2012;143(4):963-73.

6. Cooper C, Mackie D. Hepatitis B surface antigen-1018 ISS adjuvantcontaining vaccine: a review of HEPLISAV safety and efficacy. Expert Rev Vaccines. 2011;10(4):417-27.

7. Halperin SA, Ward BJ, Dionne M, Langley JM, McNeil SA, Smith B, et al. Immunogenicity of an investigational hepatitis B vaccine (hepatitis B surface antigen co-administered with an immunostimulatory phosphorothioate oligodeoxyribonucleotide) in nonresponders to licensed hepatitis B vaccine. Hum Vaccin Immunother. 2013;9:9(7).

8. Vandepapeliere P, Lau GK, Leroux-Roels G, Horsmans Y, Gane E, Tawandee $T$, et al. Therapeutic vaccination of chronic hepatitis $B$ patients with virus suppression by antiviral therapy: a randomized, controlled study of co-administration of $\mathrm{HBsAg} / \mathrm{ASO} 2$ candidate vaccine and lamivudine. Vaccine. 2007;25(51):8585-97.

9. Xu DZ, Zhao K, Guo LM, Li LJ, Xie Q, Ren H, et al. A randomized controlled phase Ilb trial of antigen-antibody immunogenic complex therapeutic vaccine in chronic hepatitis B patients. PLoS One. 2008;3(7), e2565.

10. Hoa PT, Huy NT, Thu IT, Nga CN, Nakao K, Eguchi K. Randomized controlled study investigating viral suppression and serological response following pre-S1/pre-S2/S vaccine therapy combined with lamivudine treatment in HBeAg-positive patients with chronic hepatitis B. Antimicrob Agents Chemother. 2009;53(12):5134-40.

11. Gaggar A, Coeshott C, Apelian D, Rodell T, Armstrong BR, Shen G, et al. Safety, tolerability and immunogenicity of GS-4774, a hepatitis B virusspecific therapeutic vaccine, in healthy subjects: a randomized study. Vaccine. 2014;32(39):4925-31.

12. Krawczyk A, Ludwig C, Jochum C, Fiedler M, Heinemann FM, Shouval D, et al. Induction of a robust $T$ - and $B$-cell immune response in non- and low-responders to conventional vaccination against hepatitis $\mathrm{B}$ by using a third generation PreS/S vaccine. Vaccine. 2014;32(39):5077-82.

13. Bauer $T$, Jilg W. Hepatitis B surface antigen-specific T and B cell memory in individuals who had lost protective antibodies after hepatitis B vaccination. vaccine. 2006;24(5):572-7.

\section{Submit your next manuscript to BioMed Central and take full advantage of:}

- Convenient online submission

- Thorough peer review

- No space constraints or color figure charges

- Immediate publication on acceptance

- Inclusion in PubMed, CAS, Scopus and Google Scholar

- Research which is freely available for redistribution

Submit your manuscript at www.biomedcentral.com/submit 